\title{
Llyn Teifi spillway rehabilitation works
}

Richard Margrett BSC (Hons), CEng, MICE

Civil Engineer, Stantec, Bristol, UK (richard.margrett@stantec.com)

The paper describes the design of the remedial works carried out in 2016 to the overflow and spillway at Llyn Teifi reservoir in west Wales; to comply with recommendations made in the 2013 Statutory Inspection report, to reduce the significant seepage that was occurring and also to improve the stability of the concrete structure. These works comprised the addition of a concrete wedge to the downstream face of the spillway and the addition of a waterproofing geocomposite membrane to the upstream face and overflow weir, together with investigations of the existing concrete. Due to the necessity to keep the reservoir at or near its normal operating level for the duration of the works in order to maintain supplies to customers in the area, the installation of the waterproofing membrane was substantially completed by divers working underwater.

\section{Background}

\subsection{Llyn Teifi reservoir}

The Teifi Pools is a group of four lakes - Llyn Teifi, Llyn Hir, Llyn Gorlan and Llyn Egnant - located on the western slopes of the Cambrian Mountains in Ceredigion, west Wales. Formed by glacial action and at up to $455 \mathrm{~m}$ above sea level, the local climate and poor acidic soils create a landscape devoid of tree cover and with very little evidence of human activity. Llyn Teifi is the largest of the four lakes and the source of the Afon Teifi, which is recognised as one of the most pristine and least modified river catchments in Britain.

\subsection{Main embankment construction}

Llyn Teifi reservoir was created in the early 1960s by raising a natural lake and is impounded behind six embankments constructed across natural low spots along its south-western margin. It covers an area of just over 25 ha and has a capacity at full supply level of around $848000 \mathrm{~m}^{3}$.

The main embankment is an earth embankment with a central $1.82 \mathrm{~m}$ wide concrete core that appears to be taken down through the Glacial Till to rockhead with a grouted cut-off that extends up to $22 \mathrm{~m}$ into the underlying greywacke bedrock. It has a crest length of $160 \mathrm{~m}$ and attains a maximum height of $5 \mathrm{~m}$ above original ground level. The upstream shoulder slopes at around 1 in 2.5 and is protected by $300 \mathrm{~mm}$ thick stone pitching while the downstream shoulder slopes at around 1 in 2 and is grassed. The upstream face terminates at the base of a $0.6 \mathrm{~m}$ high concrete wave wall that extends along the length of the dam crest. The main embankment also includes the main piped outlets from the reservoir and its overflow.

\subsection{Overflow and spillway}

The overflow comprises a concrete gravity dam to the north end of the main embankment, formed between abutment walls and with a crest length of just under $19 \mathrm{~m}$. The draw-off tower containing the piped raw water supply and scour outlets is integral with the spillway structure and located immediately to its right (north).

The spillway is divided into three monoliths, the central one being slightly wider than the outer two. The downstream spillway face clearly shows that each of the monoliths was constructed in a number of separate lifts but the record drawings provide no details of either horizontal or vertical joint arrangements.

The record drawings show the maximum height of the spillway dam, between present full supply level and the base of the foundation, to be around $11.5 \mathrm{~m}$ and to include no underdrainage or pressure-relief. A footbridge spans between the abutments at a minimum of $0.79 \mathrm{~m}$ above the current weir level. The downstream face of the spillway is inclined at about $56^{\circ}$ to the horizontal $(1.5 \mathrm{~V}: 1 \mathrm{H})$, below which there is a radiused curve into the stilling basin. A low concrete weir forms the downstream end of the stilling basin, beyond which there is a 'pitched apron', which has since been re-surfaced in concrete.

The original overflow comprised an ogee-type profile with a crest level $1.52 \mathrm{~m}$ below nominal embankment crest level and its vertical upstream face stepped back by $150 \mathrm{~mm}$ over its upper section. This was raised in 1997 through the addition of a simple ogee-type cast in situ extension, doweled into the original crest and with maximum cross-sectional dimensions $1288 \mathrm{~mm}$ long $\times 900 \mathrm{~mm}$ high. The extension was cast in three sections with the movement joints lined up with contraction joints below.

A plan and typical cross-section $(\mathrm{C}-\mathrm{C})$ through the overflow and spillway is shown in Figure 1.

\section{Statutory inspection 2012}

A statutory inspection under Section 10 of the Reservoirs Act 1975 was made by Mr J.D. Gosden of Jacobs on 11 September 2012. In the report of that inspection, the following 

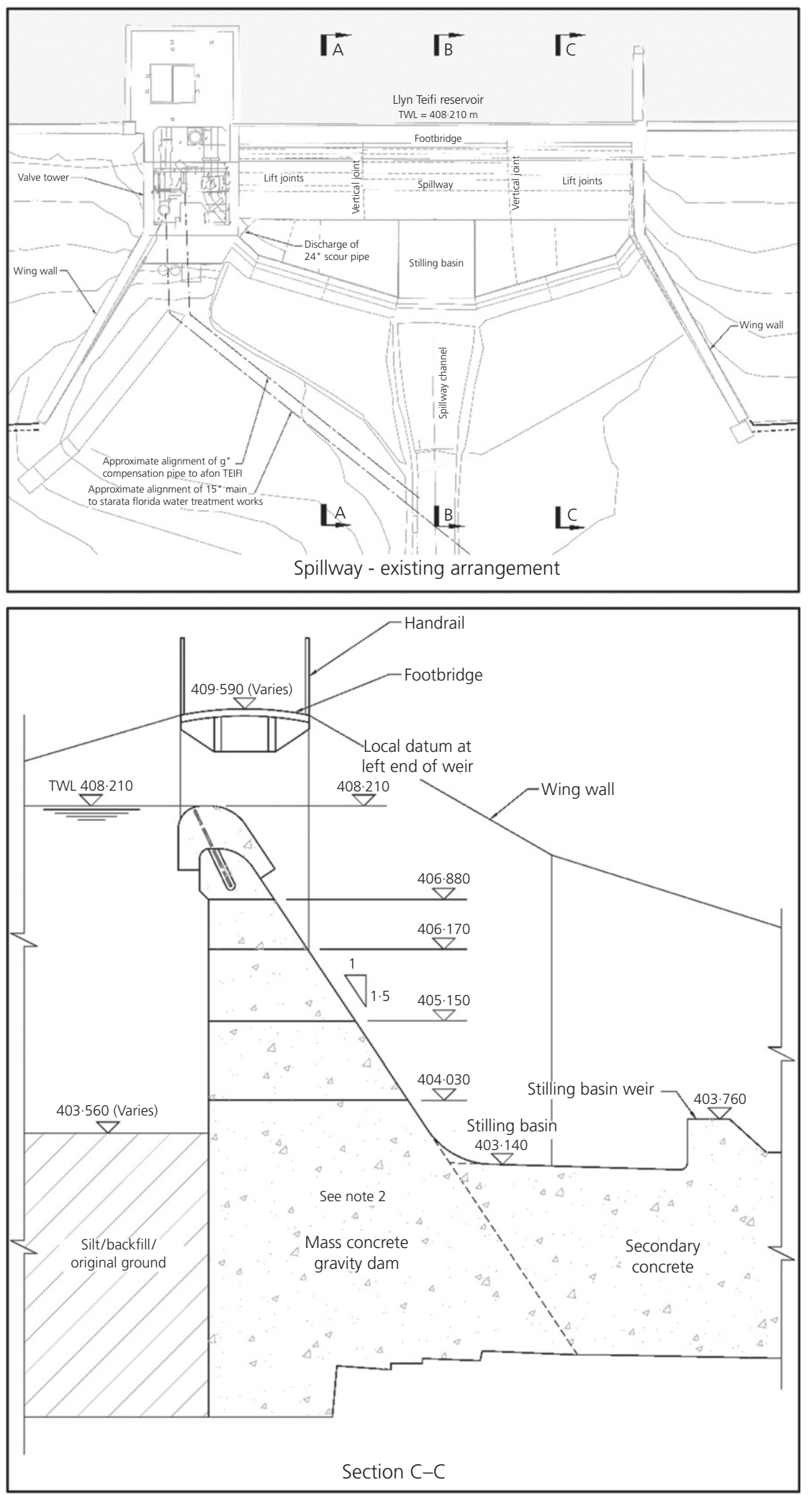

Figure 1. Plan and typical cross-section through overflow and spillway 
recommendations (among others) were made as to measures to be taken in the interests of safety under Section 10(6) of the Act

(a) Remedial works are undertaken to the concrete gravity section to control seepage paths, which are likely to be contributing to deterioration of the concrete and reduction in stability. As part of the investigation of options for this, the condition of the body of the concrete should be ascertained to determine whether any other works are required to arrest the deterioration of the concrete.

(b) In addition to controlling the seepage through the structure, further works should be undertaken to improve the stability of the concrete gravity structure.

\subsection{Seepage}

The spillway has suffered significant seepage through various joints and defects with various attempts having been made to rectify the situation over the years. In 1984, the reservoir had been drained to allow refurbishment of both the upstream and downstream joint faces. However, by 2003, when Black \& Veatch carried out an inspection, it was reported that 'when water levels are high, the top two horizontal construction joints (about $400 \mathrm{~mm}$ and $700 \mathrm{~mm}$ below the underside of the recent crest raising structure) each show evidence of a direct seepage path, with spouts of water emerging during heavy wave action. Even with the water level $1.15 \mathrm{~m}$ down during this inspection there was evidence of seepage from both of these joints' (Ackers, 2003: p. 10).

Figure 2(a) is a photograph from January 2011 with ice coverage on the downstream spillway face identifying seepage locations; Figure 2(b) is from February 2016 and clearly shows evidence of both the continued seepage and joint deterioration, particularly at the connection of the raised overflow section with the abutments.

\subsection{Concrete deterioration}

Ackers (2003: p. 10) inspection also noted that 'the exposed downstream face of the spillway has evidently deteriorated over the years, presumably due to the combined effects of seepage and surface weathering aggravated by the acidic water. There is no evidence on the main face of leaks self-healing through calcite deposition which indicates that the concrete matrix is in poor condition'. Although access to the downstream face of the spillway was not possible due to conditions at the time of the inspection, Gosden's (2013: p. 19) statutory inspection report recorded that 'The concrete of the downstream surface of the overflow gravity section is reported by Dŵr Cymru Welsh Water staff to be quite soft and in places can be gouged with keys'.

\subsection{Stability}

The recommendation to further improve stability of the concrete gravity section was made on the basis of stability analyses carried out by Black \& Veatch in 2004/2005. These had concluded that although 'major repairs are not required in the interests of safety at this stage' (Black \& Veatch, 2005: p. 25) and 'the factor of safety against sliding (shear-friction) meets the acceptance criteria for all load combinations considered except those where cohesion is disregarded' (Black \& Veatch, 2005: p. 24)

- The factor of safety against overturning does not meet the acceptance criteria for normal, unusual and extreme load combinations. The heel of the structure would be in

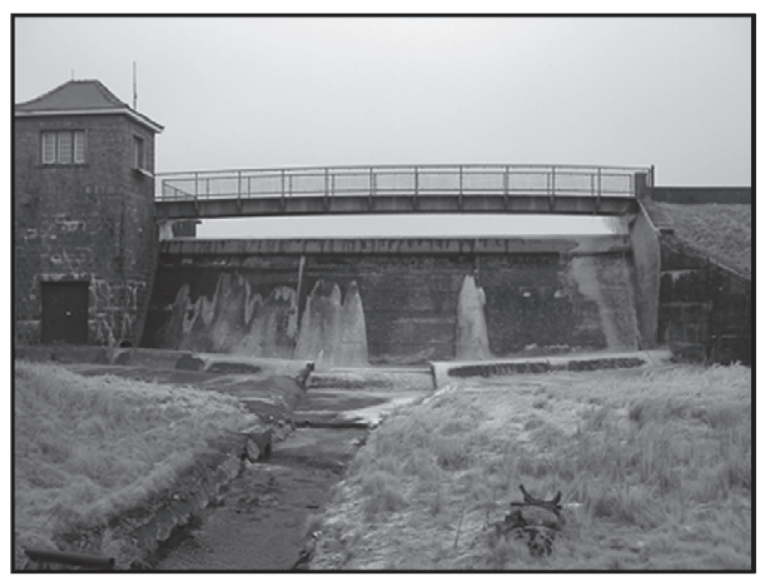

(a)

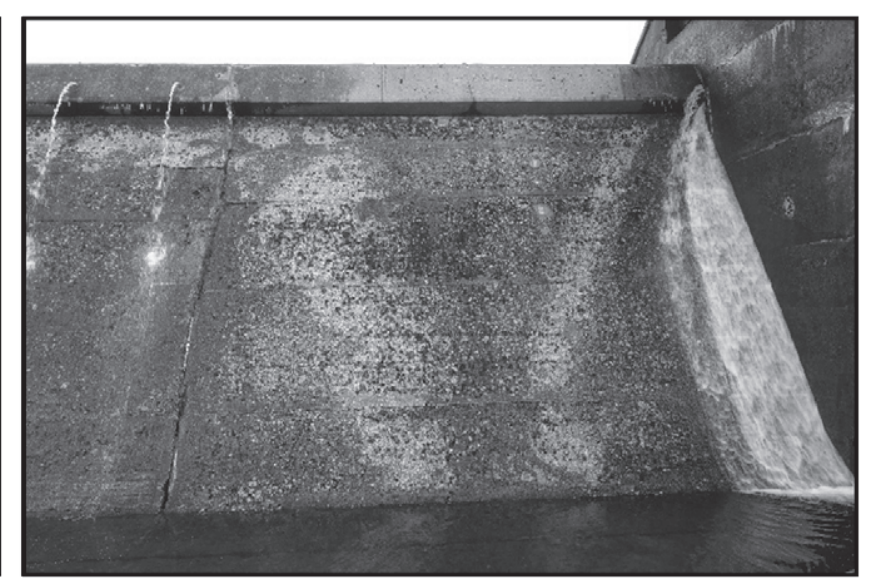

(b)

Figure 2. Spillway leakage and joint deterioration: (a) January 2011; (b) February 2016 
tension. However, it was noted that the tensile stress at the heel is well within the anticipated tensile stress capacity for the lift joints, which suggests that any crack initiating at the heel may not be able to propagate and lead to failure.

- Factors of safety against overturning are lower for the lower lift joints (e.g. varying from $1 \cdot 17$ for the first lift joint below the crest to 0.99 at the level of the stilling basin for the unusual load condition).

\section{Feasibility}

In July 2014, Dŵr Cymru Welsh Water appointed MWH (now Stantec) to assess options to satisfy the recommendations made in the 2013 Section 10 report and, in particular, to investigate the feasibility of installing a proprietary Carpi Tech geocomposite membrane on the upstream face of the structure to reduce both leakage and uplift forces.

\subsection{Constraints}

A number of constraints were apparent from an early stage. The most significant was the requirement that all works be carried out with the reservoir at, or close to, its normal operating level. Llyn Teifi supplies around two thirds of the raw water to Strata Florida Water Treatment Works and it was decided that the risks associated with lowering the reservoir to any significant extent would pose too high a risk of supply interruptions, particularly if works were undertaken during the summer. In the winter months in particular, Llyn Teifi can become almost inaccessible due to snow and ice cover and at other times, being exposed, often suffers high rainfall and very strong winds.

Access for construction plant and equipment would also be difficult at any time of the year, vehicular access being by way of $1 \mathrm{~km}$ long private metalled track approximately $2.5 \mathrm{~m}$ wide, which leaves a winding minor public road around $4.5 \mathrm{~km}$ east of the village of Ffair-Rhos. The only access to the front face of the spillway would be by way of a steeply inclined section of rough track.

Together with the River Teifi, Llyn Teifi and the other Teifi Pools also comprise the Afon Teifi special area of conservation (SAC). They also fall within the Elenydd Mallaen special protection area (SPA) and Elenydd site of special scientific interest (SSSI). Any improvement works would therefore need the assent of Natural Resources Wales.

\subsection{Site investigations}

At feasibility stage, two main investigations were undertaken; a diving survey to confirm conditions upstream of the concrete gravity structure and coring and testing of concrete from the downstream concrete face.

The diving survey by Edwards Diving Services Ltd confirmed that the overall condition of the upstream face of the spillway blocks was reasonable. The concrete surface was generally smooth, although an exposed aggregate finish was fairly widespread with a maximum aggregate protrusion of around $5 \mathrm{~mm}$. Much of the upstream face was covered in a thin layer of algae which was estimated to be less than $5 \mathrm{~mm}$ in thickness. It determined a reservoir bed level of around $4.6 \mathrm{~m}$ below the overflow weir crest.

The nature of the reservoir bed just upstream of the spillway comprised a thin veneer of soft silt that typically measured around $30 \mathrm{~mm}$ in thickness. The silt was found to overlay a hard bed of gravels and cobbles. An old concrete plinth of varied condition was reported in sections. The bed of the reservoir in front of the spillway was littered with debris including masonry and old pieces of metal work.

Concrete investigations (Geotechnical Engineering Limited, 2015) comprised a series of nine $100 \mathrm{~mm}$ diameter cores, advanced normal to the spillway surface using a water flush electric drill to a maximum depth of $200 \mathrm{~mm}$. The cores were distributed evenly across the spillway, with three on each monolith block positioned at the top, middle and bottom. Testing was carried out by ACS Testing Ltd in accordance with BS EN 12504-1:2009 (BSI, 2009), BS 1881: Part 124: 1988 (BSI, 1988), BRE Digest IP6/81 (Roberts, 1981), APG SR2 (APG, 2010) and American Society for Testing and Materials (ASTM) C856-11 (ASTM, 2011) and suggested that, contrary to earlier suggestions, the concrete was in reasonable condition with a good level of compaction and no evidence of cracking/fissures or honeycombing.

Four samples were also submitted to Sandberg LLP for petrographic analysis. These showed no evidence of alkali-aggregate reaction and that the coarse and fine aggregates in all samples were composed of generally dense and robust lithologies. While the majority showed little evidence of deterioration within the concrete, all samples had been affected by substantial long-term moisture ingress resulting in recrystallisation of the cement hydrates and minor weakening of the concrete. All samples had undergone localised surface deterioration resulting from severe leaching, probably due to exposure to mobile moisture. Severe weakening/leaching was seen to depths of up to $1.4 \mathrm{~mm}$ and minor porosity enhancement was seen to depths of up to $8 \mathrm{~mm}$. There was no evidence to suggest cracking or weakening of the concrete as a result of aggregate alteration or the occurrence of sulfate attack at the external surface.

The provisional conclusions from the investigations were that

- The addition of a geocomposite membrane upstream of the concrete gravity structure should be possible but that, if installation was needed to be carried out by divers working underwater, coverage to include the lower lift joints would 
be difficult as these were well below the reservoir hard bed level.

- The concrete was in better condition than anticipated with deterioration notable only to the surface of the downstream structure face.

\subsection{Stability}

\subsubsection{4/2005 analysis}

The stability analysis in $2004 / 2005$ by Black \& Veatch identified that the factor of safety against overturning did not meet the acceptance criteria for normal/usual, unusual and extreme load combinations as set out in 'Design of Small Dams' (USBR, 1987) and reproduced below

\begin{tabular}{|c|c|}
\hline Normal/usual & $\begin{array}{l}\text { Normal design reservoir elevation with appropriate } \\
\text { dead loads, uplift, silt, ice and tailwater. If } \\
\text { temperature loads are applicable to the specific } \\
\text { sites, use minimum usual temperatures occurring } \\
\text { at that time. }\end{array}$ \\
\hline Unusual & $\begin{array}{l}\text { Maximum design reservoir elevation with } \\
\text { appropriate dead loads, silt, tailwater, uplift and } \\
\text { minimum usual temperatures occurring at that } \\
\text { time, if applicable. }\end{array}$ \\
\hline Extreme & $\begin{array}{l}\text { The usual loading plus the effect of the maximum } \\
\text { credible earthquake (MCE). }\end{array}$ \\
\hline
\end{tabular}

Table 1 sets out the specific parameters adopted for Llyn Teifi; Table 2 shows selected results from the analysis of the overturning stability of the central monolith, noting that the factors of safety against sliding were all found to be acceptable.

\subsubsection{5 analysis}

MWH (now Stantec) updated the 2005 stability analysis with stability checks as described in the more recent guidance 'Stability Analysis of Concrete Structures' (USACE, 2005). Table 3 sets out selected results of this analysis for comparison with Table 2; Table 4 shows the loading combinations considered.

It can be seen that, using the more recent guidance, sliding represents the critical case with factors of safety well below those required for both extreme (flood) and extreme (seismic). It was also identified that the upstream face would be in tension under the 'Usual' scenario.

\section{Options evaluation}

It was recognised from an early stage that installation of a carefully designed, waterproof geocomposite membrane to the upstream face of the spillway structure should address the leakage issues and also improve the stability of the concrete overflow structure. However, particularly after the diving survey, it was also recognised that it would be difficult to take the membrane down to below the lower lift joints which had the lowest factors of safety against sliding.

Two main complementary options were therefore considered

(A) The addition of a concrete wedge to the downstream face of the spillway.

(B) Post-tensioned anchors.

A third option - un-tensioned dowels - was also considered but rejected as tension forces would theoretically give rise to

Table 1. Load combinations and selected parameters

\begin{tabular}{|c|c|c|c|c|c|c|c|c|}
\hline \multirow[b]{2}{*}{$\begin{array}{l}\text { Load } \\
\text { combin-ation }\end{array}$} & \multirow[b]{2}{*}{$\begin{array}{l}\text { Reservoir } \\
\text { level: m OD }\end{array}$} & \multirow[b]{2}{*}{ Tail-water } & \multirow[b]{2}{*}{ Uplift } & \multirow[b]{2}{*}{$\begin{array}{l}\text { Overtopping } \\
\text { pressures }\end{array}$} & \multirow[b]{2}{*}{$\begin{array}{c}\text { Friction angle: } \\
\text { degrees }\end{array}$} & \multirow[b]{2}{*}{$\begin{array}{c}\text { Cohesion: } \\
\text { kPa }\end{array}$} & \multicolumn{2}{|c|}{$\begin{array}{l}\text { Seismic loads applied } \\
\text { (pseudo-static) }\end{array}$} \\
\hline & & & & & & & Horizontal & Vertical \\
\hline Normal/usual & $408 \cdot 209$ (full supply) & Not applied & Full uplift & None & 55 & 100 & No & No \\
\hline Unusual & 408.859 (flood level) & Not applied & Full uplift & None & 55 & 100 & No & No \\
\hline Extreme & $408 \cdot 209$ (full supply) & Not applied & Full uplift & None & 55 & 100 & Yes 0.12 & Yes 0.08 \\
\hline
\end{tabular}

Table 2. Selected results from 2005 analysis by Black \& Veatch

\begin{tabular}{|c|c|c|c|c|c|c|}
\hline \multirow[b]{2}{*}{ Lift joint } & \multirow{2}{*}{$\begin{array}{c}\text { Joint level } \\
\text { (overflow level at } 408 \cdot 21 \text { m OD) }\end{array}$} & \multicolumn{3}{|c|}{ Overturning factor of safety } & \multirow{2}{*}{$\begin{array}{c}\text { Maximum tensile stress } \\
\text { at heel: } \mathrm{kPa}\end{array}$} & \multirow{2}{*}{$\begin{array}{l}\text { Case giving maximum } \\
\text { tensile stress }\end{array}$} \\
\hline & & Normal & Unusual & Extreme & & \\
\hline$C 7$ & $406 \cdot 847$ & 1.87 & $1 \cdot 17$ & $1 \cdot 34$ & $15 \cdot 5$ & Unusual \\
\hline C6 & $406 \cdot 581$ & $1 \cdot 75$ & $1 \cdot 11$ & $1 \cdot 26$ & $23 \cdot 3$ & Unusual \\
\hline C3 & $404 \cdot 840$ & $1 \cdot 37$ & 1.00 & 1.03 & $53 \cdot 7$ & Unusual \\
\hline C1 & $403 \cdot 367$ & $1 \cdot 27$ & 0.99 & 0.98 & $72 \cdot 9$ & Extreme \\
\hline \multicolumn{2}{|c|}{ Required factor of safety } & $1 \cdot 50$ & $1 \cdot 25$ & $1 \cdot 10$ & - & - \\
\hline
\end{tabular}


Table 3. Existing structure, factors of safety

\begin{tabular}{|c|c|c|c|c|c|c|c|}
\hline \multirow{2}{*}{$\begin{array}{l}\text { Lift } \\
\text { joint }\end{array}$} & \multirow{2}{*}{$\begin{array}{c}\text { Joint level (overflow level } \\
\text { at } 408.21 \text { mOD) }\end{array}$} & \multicolumn{3}{|c|}{ Uplift factor of safety } & \multicolumn{3}{|c|}{ Sliding factor of safety } \\
\hline & & Usual & Extreme (Flood) & Extreme (Seismic) & Usual & Extreme (Flood) & Extreme (Seismic) \\
\hline C7 & $406 \cdot 847$ & $2 \cdot 86$ & 2.09 & $2 \cdot 71$ & $>100$ & $70 \cdot 16$ & $76 \cdot 82$ \\
\hline C6 & $406 \cdot 581$ & $2 \cdot 85$ & $2 \cdot 13$ & $2 \cdot 73$ & $>100$ & $60 \cdot 47$ & $64 \cdot 02$ \\
\hline C3 & $404 \cdot 840$ & $2 \cdot 74$ & $1 \cdot 24$ & $2 \cdot 69$ & $45 \cdot 53$ & 0.49 & $15 \cdot 89$ \\
\hline C1 & $403 \cdot 367$ & 1.94 & $1 \cdot 22$ & 1.93 & $18 \cdot 35$ & 0.42 & 0.99 \\
\hline \multicolumn{2}{|c|}{ Required factor of safety ${ }^{\mathrm{a}}$} & $1 \cdot 3$ & $1 \cdot 1$ & $1 \cdot 1$ & $2 \cdot 0$ & $1 \cdot 1$ & $1 \cdot 1$ \\
\hline
\end{tabular}

${ }^{a}$ Critical structure, ordinary site information

Selected results from 2015 analysis by MWH, now Stantec

Table 4. Load combinations from 2015 analysis by MWH, now Stantec

\begin{tabular}{|llll}
\hline Load combination & Water level: $\mathbf{m}$ OD & Seismic loading \\
\hline 1 & Unusual - construction & None & None \\
2 & Usual - normal reservoir condition & $408 \cdot 21$ & None \\
3 & Unusual - 1 in 150 year flood & 408.43 & None \\
4 & Extreme - construction and operational basis earthquake (OBE) & Not modelled & \\
5 & Unusual - normal reservoir condition and OBE & $408 \cdot 21$ & PGA: 0.06g/SGA: 0.03g (all horizontal) \\
6 & Extreme - normal reservoir condition and maximum & 408.21 & PGA: 0.125g/SGA: 0.0625g (all horizontal) \\
7 & design earthquake (MDE) & 408.86 & None
\end{tabular}

PGA, peak ground acceleration; SGA, sustained ground acceleration

cracking; in the extreme cases through the full cross-section of the spillway structure.

\subsection{Option A - addition of a concrete wedge}

The form of this is shown in Figure 3, infilling beneath the overhang of the raised weir and effectively negating the need to patch repair degraded areas of concrete to the downstream spillway face.

Table 5 shows the factors of safety when analysed in conjunction with an upstream geocomposite membrane installed to just below the second original lift joint.

\subsection{Option B - post-tensioned anchors}

This scenario assumed that ground anchors would be drilled from $406.5 \mathrm{~m}$ OD (outer diameter) on the downstream face at an angle of $80^{\circ}$ to the horizontal as shown in Figure 4 and giving a tension of $40 \mathrm{kN} / \mathrm{m}$ run of the structure.

Table 6 shows the improved factors of safety arising from the installation of anchors together with the geocomposite membrane.

In this scenario, tension at the upstream face of the spillway structure would also be avoided in the 'Usual' case.

\subsection{Preferred option}

The concrete wedge, in conjunction with the upstream geocomposite membrane, was selected as the preferred option, the post-tensioned anchor option having a number of challenges/ disadvantages, notably

- A specialist installation contractor would need to be mobilised to site for only a limited number of anchors.

- Removal and replacement of the spillway bridge might be required to permit installation to take place. This could make installation of the geocomposite membrane difficult or require it to be done either before anchor installation commenced or after it had completed.

- Inspection and testing of the anchors would represent an on-going commitment to Dŵr Cymru Welsh Water.

- Concrete remedial works would still be required to the downstream concrete face.

\section{Solution design}

Detailed design of the concrete wedge was done by $\mathrm{MWH}$ (now Stantec) with Carpi Tech appointed as a sub-consultant to develop proposals for the upstream geocomposite membrane.

\subsection{Concrete wedge}

Design of the wedge was carried out using STAAD Finite Element Analysis software, in accordance with 


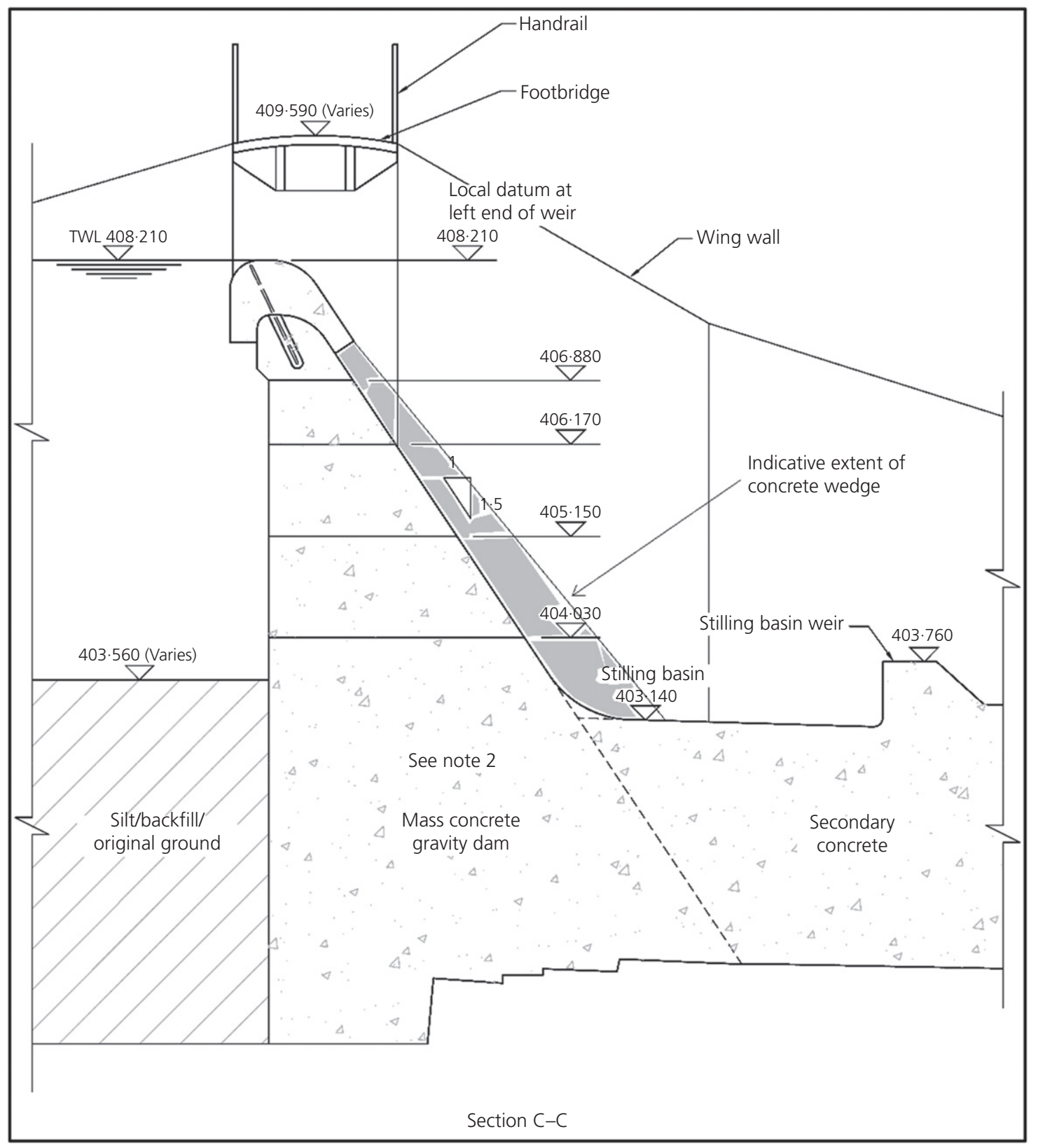

Figure 3. Indicative concrete wedge section

Eurocode 2, assuming a PMF top water level of $408 \cdot 859 \mathrm{~m}$ and a reduced factor of safety of 1.2 reflecting the extreme nature of such an event. This required that $25 \mathrm{~mm}$ diameter galvanised high tensile steel L-shaped bars be drilled and fixed into the downstream concrete face of the existing spillway on a typical $1200 \mathrm{~mm}$ square grid using Hilti HIT-RE 500-SD chemical anchors with an embedment length of $600 \mathrm{~mm}$. Dowels were also drilled vertically into the base of the existing spillway and into the abutment walls.
Reinforcement for the wedge itself was designed to be continuous over the full width of the concrete spillway and comprised a single layer of B1131 mesh to each face supplemented with B16 bars at $200 \mathrm{~mm}$ centres.

A $500 \mathrm{~mm}$ wide proprietary drainage layer with perimeter hydrophilic waterstops was specified to be applied to the full height of each of the existing vertical spillway joints with $100 \mathrm{~mm}$ diameter drainage pipes running through the base of the new concrete wedge. 
Table 5. Concrete wedge and geocomposite membrane factors of safety

\begin{tabular}{|c|c|c|c|c|c|c|c|}
\hline \multirow{2}{*}{$\begin{array}{l}\text { Lift } \\
\text { joint }\end{array}$} & \multirow{2}{*}{$\begin{array}{l}\text { Joint level (overflow } \\
\text { level at } 408.21 \mathrm{~m} \text { OD) }\end{array}$} & \multicolumn{3}{|c|}{ Uplift factor of safety } & \multicolumn{3}{|c|}{ Sliding factor of safety } \\
\hline & & Usual & Extreme (Flood) & Extreme (Seismic) & Usual & Extreme (Flood) & Extreme (Seismic) \\
\hline $\mathrm{C7}$ & $406 \cdot 847$ & $7 \cdot 79$ & $5 \cdot 41$ & $7 \cdot 79$ & $>100$ & $86 \cdot 45$ & $91 \cdot 67$ \\
\hline C6 & $406 \cdot 581$ & $9 \cdot 56$ & $6 \cdot 53$ & $9 \cdot 56$ & $>100$ & 73.66 & $75 \cdot 41$ \\
\hline C3 & $404 \cdot 840$ & $26 \cdot 89$ & $17 \cdot 47$ & $26 \cdot 89$ & $57 \cdot 50$ & $41 \cdot 51$ & $37 \cdot 50$ \\
\hline C1 & $403 \cdot 367$ & $2 \cdot 61$ & 1.42 & $2 \cdot 61$ & $37 \cdot 25$ & $10 \cdot 19$ & 19.98 \\
\hline \multicolumn{2}{|c|}{ Required factor of safety ${ }^{a}$} & $1 \cdot 3$ & $1 \cdot 1$ & $1 \cdot 1$ & $2 \cdot 0$ & $1 \cdot 1$ & $1 \cdot 1$ \\
\hline
\end{tabular}

${ }^{a}$ Critical structure, ordinary site information

Selected results from 2015 analysis by MWH, now Stantec

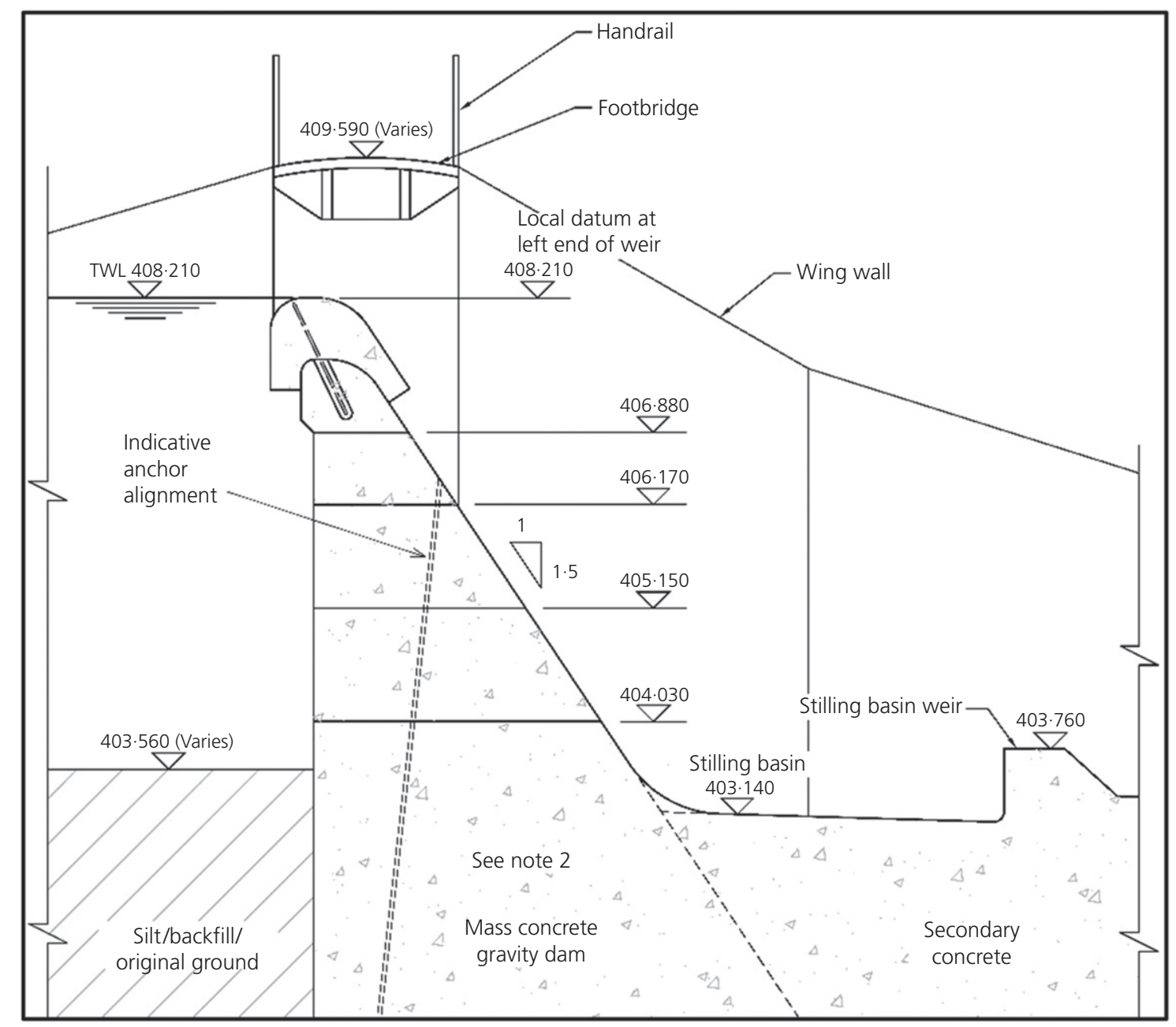

Figure 4. Indicative anchor arrangement

\subsection{Geocomposite membrane}

The system proposed by Carpi Tech for the upstream face of the concrete overflow section comprised a tensioned geocomposite liner (Sibelon CNT 3750) prefabricated from a watertight polyvinyl chloride geomembrane $2.5 \mathrm{~mm}$ thick, heat-bonded during extrusion to a non-/woven, needlepunched geotextile to provide anti-puncture resistance and drainage. This would be mechanically fastened to the 
Table 6. Post-tensioned anchors and geocomposite membrane factors of safety

\begin{tabular}{|c|c|c|c|c|c|c|c|}
\hline \multirow[b]{2}{*}{ Lift joint } & \multirow{2}{*}{$\begin{array}{c}\text { Joint level (overflow level } \\
\text { at } 408.21 \mathrm{~m} \mathrm{OD)}\end{array}$} & \multicolumn{3}{|c|}{ Uplift factor of safety } & \multicolumn{3}{|c|}{ Sliding factor of safety } \\
\hline & & Usual & Extreme (Flood) & Extreme (Seismic) & Usual & Extreme (Flood) & Extreme (Seismic) \\
\hline C7 & $406 \cdot 847$ & $7 \cdot 12$ & 4.99 & $6 \cdot 23$ & $>100$ & $71 \cdot 25$ & $77 \cdot 59$ \\
\hline C6 & $406 \cdot 581$ & 8.59 & 5.92 & $7 \cdot 53$ & $>100$ & $61 \cdot 52$ & 64.79 \\
\hline C3 & $404 \cdot 840$ & 29.08 & $18 \cdot 85$ & $25 \cdot 47$ & $53 \cdot 42$ & $37 \cdot 30$ & 34.63 \\
\hline C1 & $403 \cdot 367$ & 3.07 & 1.57 & 3.05 & 32.02 & 6.01 & 14.06 \\
\hline \multicolumn{2}{|c|}{ Required factor of safety ${ }^{a}$} & $1 \cdot 3$ & $1 \cdot 1$ & $1 \cdot 1$ & $2 \cdot 0$ & $1 \cdot 1$ & $1 \cdot 1$ \\
\hline
\end{tabular}

${ }^{a}$ Critical structure, ordinary site information

Selected results from 2015 analysis (MWH, now Stantec)



Figure 5. Cross-section through proposed improvement works

overflow structure using a Carpi Tech patented system and lapped and heat-seamed on site in accordance with the design details and allowing for installation underwater by divers.
At Llyn Teifi, the design included three separate 'compartments'; a main central compartment over the full width of the concrete spillway and two smaller compartments to each of the upstream abutment wing walls. The right-hand abutment 
wing wall which incorporated a masonry facing would have additional protection in the form of a second layer of antipuncture geotextile.

Each compartment included a drainage system to allow water trapped in the interface of the liner and the existing structures to be separately discharged by way of a common outlet point to be drilled through the base of the concrete spillway structure.

Figure 5 is a cross-section through the proposed works and shows the geocomposite liner taken over the crest of the weir and fixed to the new concrete forming the downstream face. In recognition of the increased risk of damage to this exposed section, a double layer of geocomposite was provided.

Further details are available in a separate paper (Vaschetti et al., 2018).

\subsubsection{Construction}

The contract for construction of the works was awarded to Swansea-based principal contractors Kaymac Marine and Civil Engineering Ltd with Carpi Tech as subcontractor to install the geocomposite liner system. Site works commenced on 12 September 2016 following access road improvement works carried out over the summer by Dŵr Cymru Welsh Water.

A key early requirement was the production of a dam safety management plan which covered all dam safety critical activities for the duration of the works. In particular, should significant rainfall be predicted that would likely lead to



Figure 6. Limpet dam and modular floating pontoon

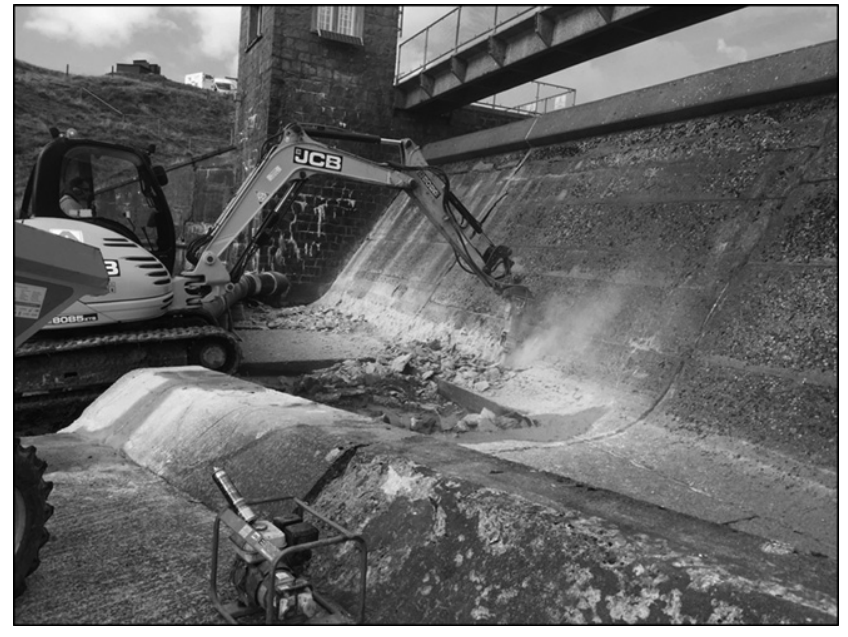

Figure 7. Concrete removal at foot of existing spillway

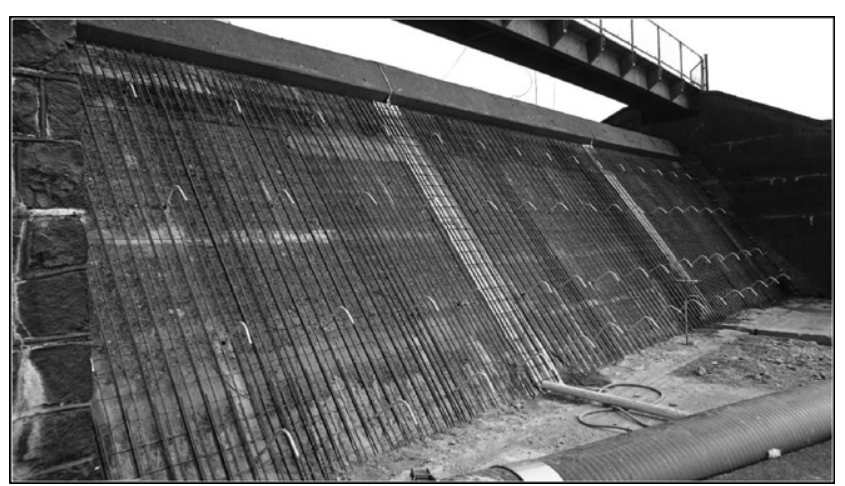

Figure 8. Reinforcement placement

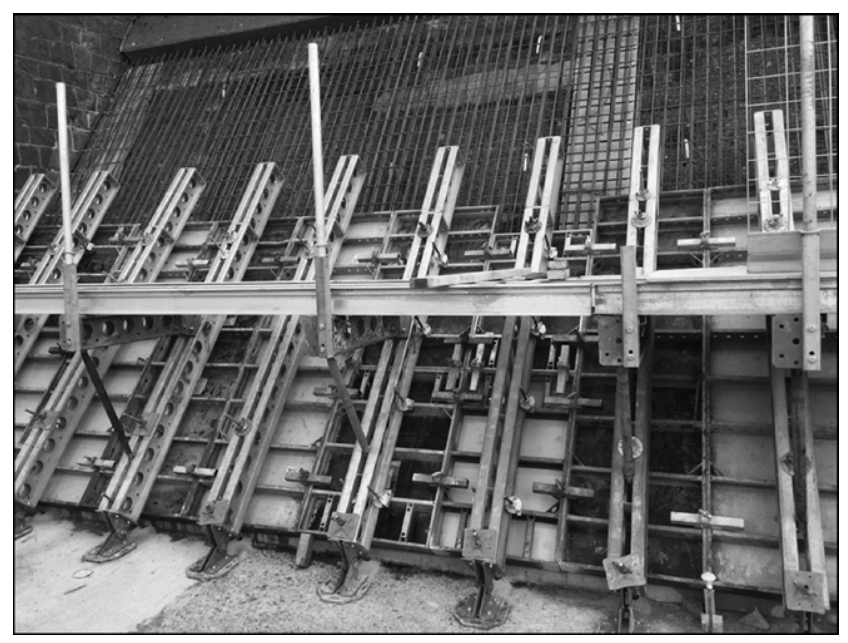

Figure 9. Formwork to downstream spillway face 




(a)



(b)

Figure 10. Liner installation: (a) to right-hand abutment; (b) Over weir crest

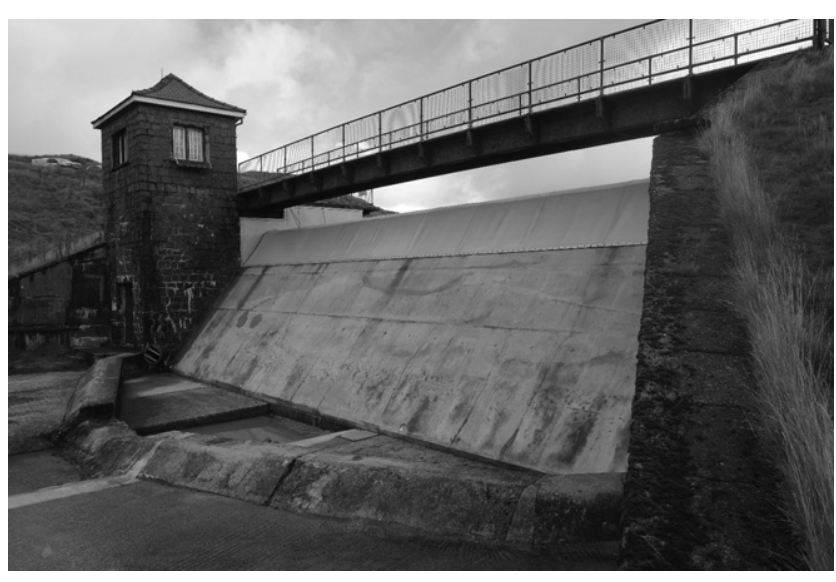

Figure 11. Completed works

operation of the overflow, arrangements were included for the contractor to remove any obstructions to the spillway and for Dŵr Cymru Welsh Water to open the scour valve beyond its usual compensation flow setting. The scour pipe itself was temporarily extended along and beyond the perimeter of the stilling basin to allow flows to be directed away from the contractor's main working area. To minimise the risk of damage to fresh concrete, pours would also be scheduled to coincide as best as possible with forecast periods of dry weather.

After the installation of further safety measures, including a scaffold access into the reservoir and a protective grille over the scour and compensation flow outlet from the reservoir, Kaymac's first task was to core drill a $175 \mathrm{~mm}$ diameter hole through the base of the existing spillway structure, install and grout in the gravity drainage pipes for each of the three liner compartments. To facilitate this Kaymac designed and fitted a limpet dam to the upstream face of the spillway using a floating modular pontoon, thereby allowing all works to be undertaken in dry conditions. A photograph of this, taken from the bridge over the spillway, is shown in Figure 6.

The rehabilitation works to the downstream spillway face involved breaking out sections of the existing concrete as shown in Figure 7, drilling and fixing steel reinforcement as shown in Figure 8, and installing a bespoke formwork system, as shown in Figure 9, to allow the new concrete to be placed to the required design profile. This was done in three vertical lifts, with access by both scaffold and mobile elevated working platforms, and using a concrete pump positioned to the north of the reservoir some $40 \mathrm{~m}$ away.

Carpi Tech, with divers from their partner, Lucatelli Diving of Trieste, commenced installation of the waterproofing liner on 26 October 2016. Figure 10 shows the installation works in progress and further details are available in a separate paper (Vaschetti et al., 2018).

All construction was completed before Christmas 2016 and Figure 11 shows the completed works.

\section{Acknowledgements}

An earlier version of this paper was published in UK Water Projects 2017. 


\section{REFERENCES}

Ackers J (2003) Llyn Teifi Reservoir - Report of an Inspection under Section 10 of the Act. Black \& Veatch Consulting Ltd, Redhill, UK. APG (Applied Petrography Group) (2010) APG SR2: A code of practice for the petrographic examination of concrete. The Geological Society, London, UK.

ASTM (2011) C856-11: Standard practice for petrographic examination of hardened concrete. ASTM International, West Conshohocken, PA, USA.

Black \& Veatch (2005) Llyn Teifi Spillway Stability Assessment. Black \& Veatch Consulting Ltd, Redhill, UK.

BSI (1988) BS 1881 Part 124:1988: Testing concrete. Methods for analysis of hardened concrete. BSI, London, UK.

BSI (2009) BS EN 12504-1:2009: Testing concrete in structures.

Cored specimen - taking, examining and testing in compression. BSI, London, UK.

Geotechnical Engineering Limited (2015) Llyn Teifi Reservoir, Factual Report on Spillway Structure Investigation. Geotechnical Engineering Limited, Gloucester, UK.
Gosden JD (2013) Teifi, Report on an Inspection carried out under the Reservoirs Act 1975, Section 10. Jacobs, Wokingham, UK.

Roberts MH (1981) BRE Digest IP6/81. Carbonation of Concrete Made with Dense Natural Aggregates. Building Research Establishment, Watford, UK.

USACE (U.S. Army Corps of Engineers) (2005) Stability Analysis of Concrete Structures, EM1110-2-2100. U.S. Army Corps of Engineers, Washington, DC, USA.

USBR (United States Bureau of Reclamation) (1987) Design of Small Dams. United States Department of the Interior, Bureau of Reclamation, Denver, $\mathrm{CO}$, USA.

Vaschetti G, Colcombe R and Lilliu G (2018) First underwater installation of a geomembrane system in a UK dam: Llyn Teifi spillway. In Smart Dams and Reservoirs. Proceedings of the 20th Biennial Conference of the British Dam Society, Swansea (Pepper A (ed.)). ICE Publishing, London, UK.

\section{How can you contribute?}

To discuss this paper, please email up to 500 words to the editor at editor@britishdams.org. Your contribution will be forwarded to the author(s) for a reply and, if considered appropriate by the editorial board, it will be published as discussion in a future issue of the journal. 